\title{
Digital Mental Health: The Answer to the Global Mental Health Crisis?
}

\author{
Brittany N Rudd ${ }^{1,2,3}$, PhD; Rinad S Beidas ${ }^{2,3,4,5}$, PhD \\ ${ }_{1}^{1}$ Institute for Juvenile Research, Department of Psychiatry, University of Illinois at Chicago, Chicago, IL, United States \\ ${ }^{2}$ Center for Mental Health, Department of Psychiatry, Perelman School of Medicine, University of Pennsylvania, Philadelphia, PA, United States \\ ${ }^{3}$ Penn Implementation Science Center, Leonard Davis Institute of Health Economics, University of Pennsylvania, Philadelphia, PA, United States \\ ${ }^{4}$ Department of Medical Ethics and Health Policy, Perelman School of Medicine, University of Pennsylvania, Philadelphia, PA, United States \\ ${ }^{5}$ Department of Medicine, Perelman School of Medicine, University of Pennsylvania, Philadelphia, PA, United States
}

\author{
Corresponding Author: \\ Brittany N Rudd, PhD \\ Institute for Juvenile Research \\ Department of Psychiatry \\ University of Illinois at Chicago \\ 1747 West Roosevelt Road, Office 218 \\ Chicago, IL, 60608 \\ United States \\ Phone: 1 (312) 9967723 \\ Email: bnrudd@uic.edu
}

\begin{abstract}
Digital mental health interventions are often touted as the solution to the global mental health crisis. However, moving mental health care from the hands of professionals and into digital apps may further isolate individuals who need human connection the most. In this commentary, we argue that people, our society's greatest resource, are as ubiquitous as technology. Thus, we argue that research focused on using technology to support all people in delivering mental health prevention and intervention deserves greater attention in the coming decade.
\end{abstract}

(JMIR Ment Health 2020;7(6):e18472) doi: $10.2196 / 18472$

\section{KEYWORDS}

public mental health; universal mental health prevention; digital implementation support

\section{Introduction}

Mental health is public health. Depression is a leading cause of disability worldwide and is estimated to affect 264 million people globally [1]. Every day 129 Americans die by suicide and 130 die by opioid overdose [2,3]. For nearly every leading cause of death (eg, cancer, heart disease), comorbid mental health disorders increase morbidity and mortality rates. For example, heart disease is the leading cause of death in the United States. Depression increases the risk for coronary heart disease among healthy adults [4,5] and mortality among patients with coronary heart disease [5,6]. To address global public health, we must address mental health.

A comprehensive public health response to disease elimination requires the use of three interrelated services that span prevention and intervention. These three services include universal prevention to limit the development of the disease, targeted intervention among those at greatest risk for acquiring the disease, and intensive intervention to treat those already experiencing the disease. The dominant paradigm for promoting mental health in society is the provision of clinical services to individuals in specialized mental health care facilities, which represents an intensive public health intervention. However, most people in the world with a mental health disorder receive no treatment [7]. Among people who actually receive care, few receive an effective treatment. For example, only $16.5 \%$ of people with major depressive disorder receive minimally adequate treatment globally [8]. Although the causes of this treatment-use gap are multifactorial, it is partly due to the dramatic shortage of specialty mental health care providers. The supply of mental health professionals does not meet the demand for mental health care. By 2025, the United States is projected to have shortages in nearly every type of mental health care provider (eg, psychiatrist, psychologist, social worker) [9]. Mental health workforce shortages are even more profound in 
low- and middle-income countries. The median number of psychiatrists available per 100,000 individuals in high-income countries is 172 times greater than in low-income countries, where there is approximately 0.05 psychiatrists per 100,000 individuals [10]. We require novel models of intervention delivery [11] as well as a paradigm shift toward a comprehensive public mental health response [12] if we are to overcome this global mental health crisis.

A total of $90 \%$ of American adults use the internet [13] and $96 \%$ own a cellphone [14]. The global penetration rate of the internet is 53\%, and although the lowest rates are among Central Africa and Southern Asia, these regions are also experiencing the fastest growth [15]. Widely celebrated as the solution to the supply and demand imbalance in mental health care, digital mental health interventions have flooded the market place to supplement specialty mental health care. However, the evidence supporting their efficacy is mixed [16,17], and engagement with digital mental health interventions, particularly mobile apps that lack ancillary human interaction, is abysmal [18]. Users are unlikely to use these interventions more than a few times. Particularly concerning is the fact that some digital mental health apps share user data without disclosing this in their privacy policy [19]. Furthermore, the movement of specialty mental health care, an intensive public health intervention, from the hands of clinicians and into standalone digital interventions ignores decades of research about the importance of social support and may further isolate individuals who need human connection the most. Given the robust social support literature, it is not surprising that digital interventions with the highest levels of engagement are those that include some form of human interaction [20,21]. In this commentary, we argue for a renewed focus on universal mental health prevention and targeted intervention [22]. We propose that people, our society's greatest resource, are as ubiquitous as technology. Thus, research focused on using technology to support all people in their delivery of universal prevention and targeted intervention deserves greater attention in the coming decade. We believe that it is the synergy of people and technology that will allow us to overcome the global mental health crisis, not technology alone.

\section{The Way Forward}

To date, multiple systematic reviews and meta-analytic studies demonstrate that lay health workforces (ie, community members without advanced mental health care training) can deliver effective mental health care, including effectively screening for mental health disorders and providing psychosocial treatments for the most common psychiatric disorders [23,24]. Given the evidence supporting the use of community members in the delivery of targeted and intensive mental health interventions, we envision enabling community members to deliver all forms of public mental health interventions. This includes supporting all people in the delivery of universal interventions through their provision of social support, as well as supporting the delivery of targeted interventions. Specifically, lay individuals in the community can help identify when their loved ones or fellow community members are distressed or in crisis, provide that identified person with evidence-based support, and escalate that person to appropriate levels of care when it is needed.
Shifting the work of mental health promotion to all people is the kind of universal public mental health strategy needed to move the needle [22] and attenuate the stigma associated with mental health disorders. Our efforts need to parallel our efforts to solve other public health crises. We need mental health prevention and intervention to be like fluoride in the water-it needs to be everywhere. Given the ubiquity of people, the synergy of people empowered by technology may be the answer that provides a solution to our global mental health crisis.

To advance these efforts, we make the following suggestions:

First, all people need to be able to reliably identify when their loved one or fellow community member is in need of help. There are both active and passive ways to accomplish this goal. An active strategy may involve the dissemination of online trainings that teach all people to recognize the difference between stress, distress, and crisis, aligned with popular gatekeeper trainings [25]. However, there are also more passive strategies that harness technology. Work is underway to use data naturally available in text messages and social media to reliably predict mood states [26], including Facebook's work to develop an algorithm to predict and prevent suicide among its users [27,28]. These innovative models could eventually support people in identifying mood states in their loved ones. Perhaps in the future our cell phones can notify us when our loved one is engaging in a text message conversation reflective of an urge to use opioids.

Second, we need to distill the active ingredients of our most robust evidence-based practices into core strategies that are ready for dissemination to the public. Identification of problems must be tied to actionable and clear steps and interventions. Thus, as we develop ways for all people to identify stress, distress, and crisis in their loved ones and community members, each category must be connected to evidence-based interventions, including when to connect that person to a higher level of care. To do that, we first need to establish which evidence-based strategies are appropriate for all people to use. Perhaps our cell phones can suggest that we provide our loved one with the National Suicide Prevention Hotline number or call 911 when a loved one is in crisis. When a loved one is stressed or distressed, perhaps our cell phones can coach a friend or family member to use low-intensity evidence-based techniques, such as active listening, problem solving, and behavioral activation as was used in the Atmiyata trial among community volunteers to promote wellness and reduce distress in India [29].

Third, we need to identify the best platform for disseminating and implementing the key elements of this proposed public mental health approach. One avenue could be the public education system. Public education curriculum increasingly includes information regarding physical health promotion (eg, health eating and exercise); thus, this may be an appropriate setting for learning about mental health promotion in oneself and others. In addition, as we continue to invest in patient-facing digital interventions to promote mental health, so too should we consider investing in clinician- or support-person-facing digital implementation supports. A notable example of this work includes Naslund, Shidhaye, and Patel's [30] work to harness 
digital technology to build capacity for the implementation of evidence-based mental health intervention in nonspecialist health workers. Technology such as this could be adapted and refined so that it can be used to support all people in supporting their loved ones and community members.

Fourth, this work will require attending to several important ethical considerations. Providing mental health support places deliverers at an increased risk for experiencing secondary stress. Encouraging people to ask and provide care might meaningfully increase our population's experience with secondary stress. Suffering is human, but often people are uncomfortable sitting with the discomfort and suffering of others. Furthermore, this work begs the question of who is responsible for providing support. Is a loved one partially responsible for incidents that occur when they did not respond to their cell phone's notification? We posit that, for the most part, friends, family, and community members already worry about the health and safety of their friends, family, and community members, and often feel responsible when incidents occur. To overcome this, we want to ensure that everyone has the tools to intervene, rather than unproductively worry, when they are ready and willing. Furthermore, safeguards must be in place to prevent information collected via technology or when a friend intervenes from causing harm (eg, employment discrimination). Thus, privacy concerns must be addressed. For example, one might argue that surveillance data collected to predict high-risk behaviors, like suicidal behavior on Facebook, is protected health information and should, therefore, be subject to regulatory oversight.

To solve the mental health crisis, we need innovative and expansive solutions, and we believe that harnessing the power of people in mental health prevention and intervention delivery, supported by technology, may get us one step closer to improving public mental health.

\section{Acknowledgments}

We are thankful to Shannon Dorsey, PhD; Lorenzo Lorenzo-Luaces, PhD; Aaron R Lyon, PhD; Steve M Schueller, PhD; and John Torous, MD, MBI, who all contributed to a Twitter feed that inspired this commentary. During the writing of this commentary, the authors were supported by the National Institute of Mental Health of the National Institutes of Health under Award Number P50MH113840 (RSB as MPI) and T32MH109433 (BNR as Postdoctoral Trainee). The funders had no role in the decision to publish or preparation of the manuscript.

\section{Conflicts of Interest}

RSB receives royalties from Oxford University Press and has consulted for Merck and the Camden Coalition for Healthcare Providers.

\section{References}

1. GBD 2017 Disease and Injury Incidence and Prevalence Collaborators. Global, regional, and national incidence, prevalence, and years lived with disability for 354 diseases and injuries for 195 countries and territories, 1990-2017: a systematic analysis for the Global Burden of Disease Study 2017. Lancet 2018 Nov;392(10159):1789-1858. [doi: 10.1016/S0140-6736(18)32279-7]

2. Centers for Disease Control and Prevention. 2020. America's drug overdose epidemic: data to action URL: https://www. cdc.gov/injury/features/prescription-drug-overdose/index.html

3. American Foundation for Suicide Prevention. 2020. Suicide Statistics URL: https://afsp.org/about-suicide/suicide-statistics/

4. Pan A, Sun Q, Okereke OI, Rexrode KM, Hu FB. Depression and risk of stroke morbidity and mortality: a meta-analysis and systematic review. JAMA 2011 Sep 21;306(11):1241-1249 [FREE Full text] [doi: 10.1001/jama.2011.1282] [Medline: 21934057]

5. Shi S, Liu T, Liang J, Hu D, Yang B. Depression and risk of sudden cardiac death and arrhythmias. Psychosom Med 2017:1. [doi: 10.1097/psy.0000000000000382]

6. Barth J, Schumacher M, Herrmann-Lingen C. Depression as a risk factor for mortality in patients with coronary heart disease: a meta-analysis. Psychosom Med 2004;66(6):802-813. [doi: 10.1097/01.psy.0000146332.53619.b2] [Medline: 15564343]

7. Wang PS, Aguilar-Gaxiola S, Alonso J, Angermeyer MC, Borges G, Bromet EJ, et al. Use of mental health services for anxiety, mood, and substance disorders in 17 countries in the WHO world mental health surveys. Lancet 2007 Sep;370(9590):841-850. [doi: 10.1016/S0140-6736(07)61414-7]

8. Thornicroft G, Chatterji S, Evans-Lacko S, Gruber M, Sampson N, Aguilar-Gaxiola S, et al. Undertreatment of people with major depressive disorder in 21 countries. Br J Psychiatry 2017 Feb;210(2):119-124 [FREE Full text] [doi: 10.1192/bjp.bp.116.188078] [Medline: 27908899]

9. Health Resources and Services Administration/National Center for Health Workforce Analysis; Substance Abuse and Mental Health Services Administration/Office of Policy, Planning, and Innovation. National projections of supply and demand for behavioral health practitioners: 2013-2025. HRSA 2015. [doi: 10.1037/e476292006-001]

10. Kakuma R, Minas H, van Ginneken N, Dal Poz MR, Desiraju K, Morris JE, et al. Human resources for mental health care: current situation and strategies for action. Lancet 2011 Nov;378(9803):1654-1663. [doi: 10.1016/s0140-6736(11)61093-3] 
11. Kazdin AE. Annual research review: expanding mental health services through novel models of intervention delivery. $\mathbf{J}$ Child Psychol Psychiatr 2018 Jun 13;60(4):455-472. [doi: 10.1111/jcpp.12937]

12. Atkins MS, Frazier SL. Expanding the toolkit or changing the paradigm: are we ready for a public health approach to mental health? Perspect Psychol Sci 2011 Sep;6(5):483-487. [doi: 10.1177/1745691611416996] [Medline: 26168200]

13. Pew Research Center. 2019. Internet/broadband fact sheet URL: https://www.pewresearch.org/internet/fact-sheet/ internet-broadband/ [accessed 2020-02-13]

14. Pew Research Center. 2019. Mobile fact sheet URL: https://www.pewresearch.org/internet/fact-sheet/mobile/ [accessed 2020-02-13]

15. Kemp S. We Are Social. 2018 Jan 30. Digital in 2018: world's internet users pass the 4 billion mark URL: https://wearesocial. com/blog/2018/01/global-digital-report-2018

16. Weisel K, Fuhrmann L, Berking M, Baumeister H, Cuijpers P, Ebert D. Standalone smartphone apps for mental health-a systematic review and meta-analysis. NPJ Digit Med 2019;2:118 [FREE Full text] [doi: 10.1038/s41746-019-0188-8] [Medline: 31815193]

17. Firth J, Torous J, Nicholas J, Carney R, Rosenbaum S, Sarris J. Can smartphone mental health interventions reduce symptoms of anxiety? A meta-analysis of randomized controlled trials. J Affect Disord 2017 Aug 15;218:15-22. [doi: 10.1016/j.jad.2017.04.046] [Medline: 28456072]

18. Torous J, Nicholas J, Larsen ME, Firth J, Christensen H. Clinical review of user engagement with mental health smartphone apps: evidence, theory and improvements. Evid Based Ment Health 2018 Aug;21(3):116-119. [doi: 10.1136/eb-2018-102891] [Medline: 29871870]

19. Huckvale K, Torous J, Larsen ME. Assessment of the data sharing and privacy practices of smartphone apps for depression and smoking cessation. JAMA Netw Open 2019 Apr 05;2(4):e192542. [doi: 10.1001/jamanetworkopen.2019.2542] [Medline: 31002321]

20. Kim H, Ray CD, Veluscek AM. Complementary support from facilitators and peers for promoting mhealth engagement and weight loss. J Health Commun 2017 Nov;22(11):905-912. [doi: 10.1080/10810730.2017.1373876] [Medline: 29125393]

21. Piette JD, Marinec N, Janda K, Morgan E, Schantz K, Yujra ACA, et al. Structured caregiver feedback enhances engagement and impact of mobile health support: a randomized trial in a lower-middle-income country. Telemed J E Health 2016 Apr;22(4):261-268 [FREE Full text] [doi: 10.1089/tmj.2015.0099] [Medline: 26352854]

22. Purtle J, Nelson KL, Counts NZ, Yudell M. Population-based approaches to mental health: history, strategies, and evidence. Annu Rev Public Health 2020 Apr 02;41:201-221. [doi: 10.1146/annurev-publhealth-040119-094247] [Medline: $\underline{31905323}$ ]

23. Barnett ML, Gonzalez A, Miranda J, Chavira DA, Lau AS. Mobilizing community health workers to address mental health disparities for underserved populations: a systematic review. Adm Policy Ment Health 2018 Mar;45(2):195-211 [FREE Full text] [doi: 10.1007/s10488-017-0815-0] [Medline: 28730278]

24. Singla DR, Kohrt BA, Murray LK, Anand A, Chorpita BF, Patel V. Psychological treatments for the world: lessons from low- and middle-income countries. Annu Rev Clin Psychol 2017 May 08;13:149-181 [FREE Full text] [doi:

10.1146/annurev-clinpsy-032816-045217] [Medline: 28482687]

25. Burnette C, Ramchand R, Ayer L. Gatekeeper training for suicide prevention: a theoretical model and review of the empirical literature. Rand Health Q 2015 Jul 15;5(1):16 [FREE Full text] [Medline: 28083369]

26. Zulueta J, Piscitello A, Rasic M, Easter R, Babu P, Langenecker SA, et al. Predicting mood disturbance severity with mobile phone keystroke metadata: a biaffect digital phenotyping study. J Med Internet Res 2018 Jul 20;20(7):e241. [doi: 10.2196/jmir.9775] [Medline: 30030209]

27. Facebook. 2020. Suicide prevention URL: https://www.facebook.com/help/594991777257121

28. Tsukayama H. The Washington Post. 2017 Nov 27. Facebook is using AI to try to prevent suicide URL: https://www. washingtonpost.com/news/the-switch/wp/2017/11/27/facebook-is-using-ai-to-try-to-prevent-suicide/

29. Shields-Zeeman L, Pathare S, Walters BH, Kapadia-Kundu N, Joag K. Promoting wellbeing and improving access to mental health care through community champions in rural India: the intervention approach. Int J Ment Health Syst 2017;11:6. [doi: 10.1186/s13033-016-0113-3] [Medline: 28066505]

30. Naslund JA, Shidhaye R, Patel V. Digital technology for building capacity of nonspecialist health workers for task sharing and scaling up mental health care globally. Harvard Rev Psychiatry 2019;27(3):181-192. [doi: 10.1097/hrp.0000000000000217] 
Edited by J Torous; submitted 27.02.20; peer-reviewed by J Torous, J Zulueta; comments to author 26.03.20; revised version received 27.03.20; accepted 28.03.20; published 02.06.20

Please cite as:

Rudd BN, Beidas RS

Digital Mental Health: The Answer to the Global Mental Health Crisis?

JMIR Ment Health 2020;7(6):e18472

URL: https://mental.jmir.org/2020/6/e18472

doi: $\underline{10.2196 / 18472}$

PMID: $\underline{32484445}$

CBrittany N Rudd, Rinad S Beidas. Originally published in JMIR Mental Health (http://mental.jmir.org), 02.06.2020. This is an open-access article distributed under the terms of the Creative Commons Attribution License (https://creativecommons.org/licenses/by/4.0/), which permits unrestricted use, distribution, and reproduction in any medium, provided the original work, first published in JMIR Mental Health, is properly cited. The complete bibliographic information, a link to the original publication on http://mental.jmir.org/, as well as this copyright and license information must be included. 